\title{
Servitization of Solar Energy Sector
}

\author{
Yogita Pandey
}

\begin{abstract}
India suffers from acute power shortages, increased by an inconsistent coal supply. A strong industry-driven campaign is needed to educate and inform consumer's that solar is the key to solving power woes in the country. The objective of the paper is to show the transformation journey in the Solar Sector over the years. The paper shows various identified factors that are assumed to be influencing consumer's intention for the purchase of Solar Energy. Due to the Challenges faced by the solar industry suppliers and customers, we suggest that the industry should consider an introduction of servitization in their operations model. Under the current process of purchasing solar energy systems, the user purchases the system and is charged with the responsibility of maintenance, replacement of consumables and disposal of the equipment. The major disadvantage of solar energy products is its high price and area demand to setup a device aside from these drawbacks, the customers should think about the actual fact that solar power Products are highly beneficial not only for the environment but also for human beings for its unique feature of infinite abundant energy. A primary goal of our thesis would be to develop such business model which will operate in the field of Solar Energy sector to increase the consumer's access to solar power.
\end{abstract}

Index Terms-Business Models, Solar Energy, Servitization, Key barriers.

\section{INTRODUCTION}

Solar energy has experienced an impressive technological shift. In the beginning solar technologies consisted of small-scale photovoltaic (PV) cells, recent technologies are represented by solar concentrated power (CSP) and moreover by large-scale PV systems that feed into electricity grids. The annual global market for solar photovoltaic (PV) increased only slightly in 2018 , but enough to surpass the $100 \mathrm{GW}$ level (including on- and off-grid capacity) for the first time. The second-largest market in Asia was India, which added an estimated 10.8 GW for a total of around 32.9 GW (fig.1). Installations were down relative to the previous year, for the first time since 2014. The decline was due to several factors, including land and transmission constraints, a safeguard duty on imports from China and Malaysia (source of about $85 \%$ of India's imports of solar product), mark in the tender scheme and uncertainty surrounding the Goods and Services Tax, all of which affected large-scale installations. Investment in India's solar sector fell $27 \%$ by one estimate, despite an increase in investment in new manufacturing facilities, because of the decrease in installations and the decline in system costs. India is targeting $100 \mathrm{GW}$ of installed solar PV by fiscal year 2022.The Indian rooftop market continued to grow rapidly,

Yogita Pandey, Marketing Student, Symbiosis Institute of Business Management, Pune, India. up about two-thirds during 2018 by one estimate. But total rooftop capacity remained relatively low, reaching as much as a few GW by year's end. The rooftop market continued to consist mainly of large commercial and industrial companies, as well as government entities and educational institutions, all seeking to reduce their electricity bills; few residential customers can afford the upfront costs. As in recent years, most of India's newly installed capacity during 2018 was in large-scale installations, with the bulk of this in five states: Karnataka, Rajasthan, Andhra Pradesh, Tamil Nadu and Maharashtra. At least three of these states (Andhra Pradesh, Karnataka and Tamil Nadu) continued to face some challenges, which resulted in significant losses to project developers.

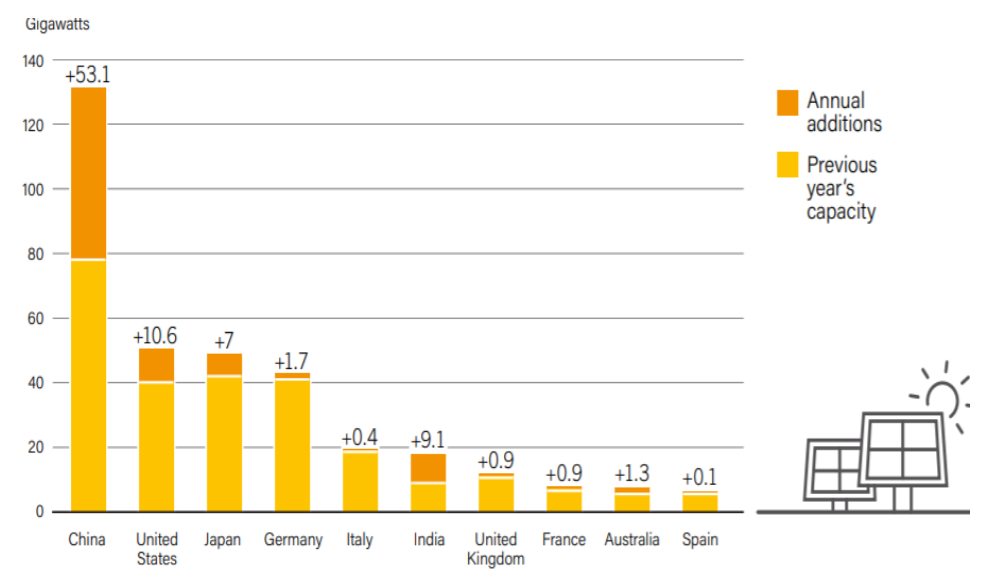

Fig.1 Solar PV Capacity and Additions, 2018.

\section{LITERATURE REVIEW}

\section{A. Servitization}

Servitization is the term given to a transformation where manufacturers increasingly offer services that are tightly coupled to their products (Baines et al., 2007). Many models within the academic press build on a distinction between products and services, illustrating how a change in the balance between these, translates to differing levels of servitization. For example, Tukker (2004) puts forwards the concepts of product oriented services, use oriented services, and result oriented services. Whereas Mathieu (2001) uses a $3 \times 3$ matrix topology with an axis of service specificity (customer service, product service, service as a product) and an axis of organizational focus (tactical, strategic and cultural).

Servitization started a new movement of including services not as a "separate category" but instead as an inherent part of a company's product offerings (Vandermerwe\& Rada, 1989). Hence, servitization can be defined as a business model innovation where the conventional manufacturers increase the scope of their 
product offerings by adding services or solutions in order to create more value (Vandermerwe\& Rada, 1989).

The responsibility lies with the integrated service or solution providers to ascertain and resolve each customer's requirements and business problem. The concept of servitization can also be explained in relation with other factors showing various inter-relationships. For example, through servitization, competitive advantage can be determined in terms of a financial factor. Because of servitization, companies have managed to be profitable despite having a reduction in their net sales (Sawhney, Balasubramanian \& Krishnan 2003). Moreover, firms which have started to offer services or solutions have shown to be more stable even during a slump in the market (Brax, 2005).

Servitization keeps customers at the focal point by offering various solutions and thereby improving customer relationships (Shepherd \& Ahmed, 2000). As for the manufacturers, they should understand that superior service is one of the most effective ways to create a win-win situation for both manufacturer and customer along with numerous long-term benefits.

\section{B. Servitization in Energy Sector}

As competition increases, servitization demonstrates an attractive strategy for manufacturers in the energy sector. A broad agreement exists that utilities need to renew their business models (Richter, 2013; Schleicher-Tappeser, 2012; Schoettl and LehmannOrtega, 2011). Several scholars have discovered business model innovation as a vehicle for transformation and renewal (Zott et. al., 2011) and as a all-inclusive concept, effecting the whole organization (Nair et. al., 2012; Amit and Zott, 2001). Moreover, industry experts and scholars propose, that utilities need to transform from commodity suppliers to energy service providers, by developing and offering comprehensive energy solutions for residential and commercial customers (Richter, 2012; Richter, 2013; Pecan Street, 2010; Valochi et al., 2010; Klose et al., 2010; Servatius, 2012; The Boston Consulting Group, 2011; PWC, 2013).This study focus on the specificities of servitization as a specific form of business model innovation in the power sector, and improves the understanding of the challenges related to such a transitions also in other capital intensive commodity industries. Asset transformation a new concept in the business model was introduced in this paper, complementing previously researched barriers such as asset re-allocation and cognitive barriers. The study furthermore suggests that companies need to develop the capability of creative accumulation (Bergek et al., 2013) namely the combination of old and new competences and technologies to comply with future market needs. Whereas previous literature considered the organizational separation of exploitative and explorative activities as appropriate (e.g. Smith and Tushman, 2005; O'Reilly and Tushman, 2004), recent contributions support the integration of such innovative activities into the established operational organizations (Gassmann et al., 2012). (Janet Bolo; BNM 746Technology Led Service)Technology is a key enabler in servitization as it provides capability that give information about product visibility. In the solar PV industry, technology will be important in monitoring the installations, maintaining service contracts and management of customer usage records and billings

\section{BARRIERS IN THE DEPLOYMENT OF SOLAR TECHNOLOGIES}

Using case studies, surveys and interviews with solar EPC and manufacturing companies, we came up with some barriers and needs in the solar sectors. The issues related to perceived government policy seeming high initial costs and maintenance, lack of product knowledge and experience, social influence, demographic factors such as education level and incomes well as lack of environmental attitude and concern may be part of the barriers to the adoption of domestic solar products. These issues have become the bottleneck that affect the sustainability of businesses in this industry.

A. Lack of understanding among key national and local institutions of basic system. Consumers are unaware of basic characteristics of the product and services available in the solar sector. The need to make client aware about the technology, its economics and right usage.

B. Complexity of subsidy structure \&Procedural Problems with several services providers (e.g. MNRE, IREDA, the Planning Commission, and the Ministry of Agriculture and Rural Development).

C. High upfront cost coupled with lengthy payback periods. High Cost associated with energy consumptions-Storage problem is also very serious.

D. Grid integration and availability.

E. Per capita land availability is very low in India. Limited area and lack of building integrated systems limit widespread application.

F. Training and development of human resources to drive industry growth and PV adoption .The limited capability to train adequate number of technicians to effectively work in a new solar energy infrastructure.

\section{AdDRESSING GAPS IN SERVITIZATION RESEARCH}

Some of the factors that made companies to adopt servitization are increased competition, complexity in the customer requirements and customer retention. The earlier studies covers companies from different sectors like transportation, telecommunication, energy, aerospace and machine tools; that took the initiative to get servitized. These companies became successful as they integrated their products, services, supply chain along with the right kind of technology and human resource. Lack of servitization research in the solar sector provided a stimulus to study the phenomenon of servitization and to develop business model which will operate to increase the consumer's access to solar power. At the same time, we also discussed the barriers that the solar sector is facing which can be overcome by incorporate servitization. 


\section{A. Issue Analysis}

There are clear benefits of incorporating servitization in solar sector stated below.

A. Selling a solution is much more necessary rather than the product only. Solar Industry are more concerned about selling products to the customers rather the efficiency and quality of their products and service. As the demand for strong service programs has grown and the market has become more complex, customers now expect an entire solution to their problem, not just a product.

B. If solar manufacturers sell long-term contracts with all-inclusive services to their customers, they will have a greater financial stability with a secure revenue stream. As service contracts guarantee regularly recurring revenue and increase probabilities for loyal customers and up sales.

C. Servitization can improve the Customer Retention Rate. As they are more aware about their customer's equipment. By constantly tracking and monitoring their technicians, supplies, vehicles and systems, manufacturers and their dealers hold the keys to the information that makes their customers' businesses more efficient.

D. By adopting servitization we can use the field service technicians as vital lead generator with the help of good mobile management system. This shows the importance of quality service and the potential for technicians to sell new product, services and contracts.

E. The need for good mobile field service management is essential so as to benefit from service contracts. Servitization depends on strong customer support, which comes with high first time fix rates and immediate help when needed. The best way to manage this data, monitor remote equipment, and manage workflows is through a central field service management system.

\section{B. Suggested Solutions}

The innovative service delivery mode Propose address the technical complexity, economies of scale, capital costs, and funding challenges of solar sector. The Business models previously concentrated more on the tangible assets such as grid, plant but the solutions that we are suggesting are replaced by intangible assets such as knowledge and customer orientation, crucial for the service oriented business model.

A. Service related technology innovations are necessary in the solar sector. Companies that are commercializing solar systems can adopt intelligent components and cloud-based software platforms to automate tasks related to customer account management, logistics monitoring, system control and real-time analytics.

B. The current challenges faced by customers of poor maintenance and equipment deterioration will be solved by entering into long term maintenance contracts for repairs and replacement of parts of the equipment and customer service is one more option to retain the customer for a long run. This will require company to employ additional technicians to carry out maintenance services or to vertically integrate their business by opening a company that will provide maintenance services as this would ensure speed and effectiveness of their response to customer needs.

C. Shared savings- Under this model, the supplier company finances the project either through its own funds or by borrowing from a third party. The supplier company takes on the performance risk of the project. The cost savings are divided between the supplier and customer at a prearranged percentage for an agreed length of time.

D. Guaranteed savings- In this case, the customer finances the design and installation of the project by borrowing funds from a third party such as a bank or through leasing the equipment. The supplier has no contractual arrangement with the bank but does assume the project risk and guarantees the energy savings made. If the savings do not reach agreed minimums the supplier company covers the difference; if they are exceeded then the customer agrees to share the savings with the supplier.

E. The Energy supply contract- This contract provides a structure in which end users are sold energy. The contractor charges fixed rates for providing required energy services to a certain level and have the liberty to act and make decisions on the installation of energy efficiency measures to reduce their own operating costs. The contractor provides all associated maintenance and operations support throughout the duration of the project.

F. The Build-Own-Operate-Transfer contract- In this contract model, the ownership of equipment is transferred from the supplier to the client at the end of a long term contract with the Build-Own-Operate-Transfer operator, before which the supplier may have designed, built, financed and operated the equipment. The charge incurred by the client includes the recovery of operating costs, capital and project profit.

G. Pay-as-you-save model, the initial capital cost is financed by the supplier company, which recovers the costs through monthly surcharges

\section{CONCLUSION}

The focus of this study was to explore the theory of servitization in the solar sector and develop business models which will operate in the field to increase the consumer's access to solar sector. The results were validated using semi-structured interviews which thereby improved the understanding of the role of the established business model and the different components for the innovation process. Supplier and manufacturers were considered for identifying the key barriers and the need to adopt servitization. It contributes to the knowledge by recognizing the key driver that leads to the transformation of a traditional manufacturing process into a product-service system. The study helps in optimizing the operations in the solar sector and creates a new system for customers that help confine 
long-term relationships with customers and exclude the competition.

\section{REFERENCES}

[1] Mathieu, Valérie. (2001). Service strategies within the manufacturing sector: benefits, costs and partnership. International Journal of Service Industry Management, 12(5), 451-475.

[2] Neely, Andy, Benedettini, Ornella, \& Visnjic, Ivanka. (2008, 2011).

The servitization of manufacturing: Further evidence. Paper presented at the Proceedings of the European Operations Management Association Conference, Cambridge, UK.

[3] https://www.ren21.net/

[4] Åhlström, Pär, \& Nordin, Fredrik. (2006). Problems of establishing service supply relationships: evidence from a high-tech manufacturing company. Journal of Purchasing and Supply Management, 12(2), 75-89.

[5] https://www.ibef.org/industry/renewable-energy.aspx

[6] Book- Basic research needs for solar energy utilization.

[7] https://mnre.gov.in

[8] Emerging Technology Opportunities for the Tianjin Binhai New Area

[9] (TBNA) and the Tianjin Economic-Technological Development Area (TEDA)

[10] Book Author(s): Richard Silberglitt, Anny Wong, S. R. Bohandy, Brian G. Chow, Noreen Clancy, Scott Hassell, David R. Howell, Gregory S. Jones, Eric Landree and Parry Norling Published by: RAND Corporation. (2009)

[11] http://www.solarpaneltalk.com/showthread.php

[12] de Vries B. J. M., van Vuuren, D. P., and Hoogwijk, M. M. (2007). Renewable energy sources: Their global potential for the first-half of the 21st century at a global level: An integrated approach. Energy Policy, 35, 2590-2610.

[13] del Río, P., and Gual, M. A. (2007). An Integrated Assessment of the Feed-in Tariff System in Spain. Energy Policy, 35(2), 994-1012

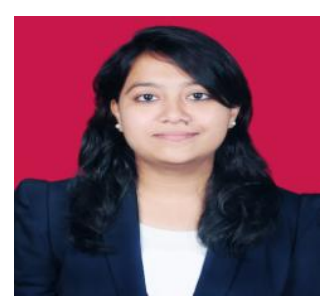

Yogita Pandey is a Student pursuing her MBA in Marketing from Symbiosis Institute of Business Management, Pune. She has completed her Electronics Engineering from University of Pune. She is a working professional having 5 years of experience in the field of Manufacturing and Energy sector. 